\title{
KLITHIH: FAKTOR RISIKO DAN DEVELOPMENTAL PATHWAY PELAKUNYA
}

\author{
Arum Febriani \\ Fakultas Psikologi Universitas Gadjah Mada, \\ Jalan Humaniora No.1 Bulaksumur Yogyakarta, 55281 \\ arum_febriani@ugm.ac.id
}

\begin{abstract}
During the recent years, klithih (juvenile crime) is considered one of the most common form of violence commited by young people in Yogyakarta. This study aimed to identify the risk factors for, and developmental pathway to, klithih among young people. Participants of this study were ten young offenders aged between 15-17 years old who were incarcerated in Juvenile Detention Center (JDC) Wonosari, Yogyakarta. Based on qualitative analysis, there were three risk factors, namely: 1) Poor parent-child relationships; 2) Commitment to deviant peer group; and 3) Low academic motivation. These risk factors influenced the development of juvenile delinquency and crime from childhood to adolescence and together they formed developmental pathway.
\end{abstract}

Keywords: adolescents, developmental pathway, risk factor, violence behavior

\begin{abstract}
Abstrak
Klithih, kasus kekerasan yang dilakukan remaja, telah dianggap sebagai salah satu kasus penting di Yogyakarta selama beberapa tahun terakhir ini. Penelitian ini bertujuan untuk mengetahui faktor risiko dan memahami developmental pathway perilaku kekerasan pelaku klithih. Partisipan adalah 10 remaja pelaku klithih berusia 15-17 tahun yang berada di Lembaga Pembinaan Khusus Anak (LPKA) Wonosari, Yogyakarta. Dari hasil analisis kualitatif didapatkan tiga faktor risiko perilaku kekerasan yaitu: 1) Relasi yang buruk dengan orangtua; 2) Komitmen dengan kelompok teman sebaya yang berperilaku menyimpang; dan 3) Rendahnya motivasi akademik. Tiga faktor risiko tersebut mempengaruhi perkembangan terbentuknya perilaku kekerasan dan bersama-sama membentuk developmental pathway perilaku kekerasan.
\end{abstract}

Kata kunci: developmental pathway, faktor risiko, perilaku kekerasan, remaja

\section{Pendahuluan}

Fenomena klithih yang marak terjadi di wilayah DIY akhir-akhir ini telah menimbulkan keresahan banyak pihak. Beberapa kejadian bahkan menelan korban jiwa, bukan sekedar luka-luka. Sepanjang 2016 kasus klithih tercatat sebanyak 43 kali yang berasal dari seluruh wilayah Polres DIY, dengan rincian kasus paling banyak terjadi di Sleman, 21 kasus, dan Bantul, 15 kasus ("Kapolda DIY," 2016). Selanjutnya, pada 
bulan Juni 2018 saja, telah terjadi empat kasus klithih dengan mayoritas pelakunya adalah anak-anak atau remaja ("Bikin miris, dalam sebulan," 2018). Oleh karena itu, tidak heran jika Polda DIY menetapkan klithih sebagai kasus yang paling diwaspadai di Yogyakarta ("Klithih menjadi kasus," 2016).

Klithih berasal dari bahasa Jawa yang artinya berjalan bolak-balik agak kebingungan (Mangunsuwito, 2002). Istilah ini biasanya ditujukan untuk orang yang mencari kesibukan, atau orang yang terbangun di malam hari, merasa lapar, dan mencari makanan (Sarwono, 2017). Jadi, istilah klithih awalnya digunakan dalam konteks positif atau netral. Namun, sekarang istilah ini telah mengalami pergeseran menjadi sesuatu yang negatif. Klithih yang dilakukan remaja pelajar di Yogyakarta merupakan bentuk tindak kejahatan (misalnya menyerang atau membunuh) yang dilakukan dengan menggunakan motor (Sarwono, 2017). Target serangan umumnya adalah siswa dari sekolah lain. Penyerangan tersebut seringkali dilakukan tanpa alasan dan tidak selalu dilandasi motif balas dendam. Oleh karena itu, klithih sudah termasuk tindak kriminalitas, bukan lagi sekedar kenakalan remaja.

Sejauh ini masih ada perdebatan apakah pelaku klithih dikategorikan sebagai anak-anak atau remaja. Pada beberapa negara, penanganan untuk anak dan remaja pelaku tindak kriminalitas masih beragam, apakah mereka bisa dikenai hukuman penjara atau harus mendapatkan diversi (Kazdin, 2003). Secara hukum di Indonesia, pelaku tindak kriminal di bawah usia 18 tahun dikategorikan sebagai 'anak-anak' dan dikenakan UU Perlindungan Anak. Apabila mereka melakukan tindak kriminalitas, penyelesaian perkaranya dilakukan di luar pengadilan, cukup sekedar kerja sosial atau rehabilitasi. Namun, menurut psikologi perkembangan, individu yang masuk kategori anak-anak adalah mereka yang berusia sampai dengan 12 tahun. Individu yang berusia 12 tahun ke atas sudah termasuk remaja (Santrock, 2014). Mereka yang berusia 17 tahun bahkan sudah mendapatkan hak-hak orang dewasa, seperti memperoleh KTP, SIM, dan memiliki hak pilih. Oleh karena itu, jika individu berusia 12 tahun ke atas melakukan kejahatan, mereka seharusnya sudah bisa dituntut untuk mempertanggungjawabkan perbuatannya secara hukum.

Pelaku klithih, yang merupakan remaja, sedang berada pada tahap perkembangan memperluas dan mengeksplorasi hubungan pertemanan (Santrock, 2014). Pada masa ini, remaja mulai mengurangi intensitas pertemuan dengan keluarga dan lebih banyak berinteraksi dengan teman. Berbeda dengan anak-anak yang berteman secara informal dan hanya dari lingkup kecil (misalnya tetangga), remaja dapat membentuk hubungan pertemanan secara formal maupun informal dari lingkup yang lebih luas (misalnya sekolah dan komunitas). Selain itu, dibandingkan anak-anak, remaja sudah lebih mampu memilih teman dan mempertahankan hubungan pertemanan tersebut (Poulin \& Chan, 2010).

Pertemanan memiliki pengaruh besar dalam perkembangan remaja (Santrock, 2014). Salah satu hal yang menonjol dalam hubungan pertemanan remaja adalah tekanan teman sebaya dan konformitas (mengikuti pandangan, nilai, atau perilaku kelompok). Kedua hal ini mencapai puncaknya pada masa remaja awal dan akan mulai menurun pada masa remaja akhir (Ashford \& LeCroy, 2010; Steinberg \& Monahan, 2007). Remaja melakukan konformitas karena mereka takut ditolak oleh teman sebaya atau kelompoknya (Peake, Dishion, Stormshak, Moore, \& Pfeifer, 2013). Konformitas ini dapat bersifat positif atau negatif. Konformitas yang bersifat positif misalnya, berupaya mengikuti klub fotografi karena teman-temannya ikut dalam klub tersebut, sedangkan konformitas yang negatif misalnya, ikut kebut-kebutan di jalanan karena ajakan teman- 
temannya.

Konformitas negatif dalam hubungan pertemanan dapat menyebabkan remaja melakukan tindakan berisiko. Tindakan berisiko adalah tindakan yang membahayakan dan merugikan pelaku dan orang lain atau masyarakat (Kipping, Campbell, MacArthur, Gunnell, \& Hickman, 2012). Gullone dan Moore (2000) menyatakan bahwa perilaku berisiko dapat dibagi menjadi empat, yaitu perilaku mencari sensasi (thrill-seeking behaviour), perilaku sembrono (reckless behaviour), perilaku memberontak (rebellious behavior), dan perilaku antisosial (antisocial behaviour). Perilaku mencari sensasi merupakan perilaku yang membangkitkan excitement, perasaan naiknya kadar adrenalin, menantang tapi masih bisa diterima lingkungan sosial, misalnya olahraga berbahaya seperti arung jeram. Perilaku sembrono juga merupakan perilaku mencari tantangan tetapi lebih berbahaya (kadar risikonya lebih tinggi), misalnya kebut-kebutan/balapan motor di jalan umum. Perilaku memberontak adalah perilaku mencari tantangan dengan melanggar aturan-aturan sosial, misalnya minum alkohol, berkelahi/tawuran. Terakhir, perilaku antisosial adalah perilaku negatif yang memiliki konsekuensi yang rendah, misalnya berjudi dan menghina orang lain. Jadi, perilaku berisiko ini secara garis besar dapat dibedakan menjadi dua yaitu, perilaku yang bukan kriminalitas (misalnya olahraga berbahaya) dan perilaku yang mengarah pada kriminalitas (misalnya berkelahi dan berjudi).

Beberapa penelitian menunjukkan perilaku berisiko ini dapat dilakukan oleh remaja laki-laki dan perempuan, meskipun terdapat perbedaan dalam dinamikanya (Pawlowski, Atwal, \& Dunbar, 2008; Reniers, Murphy, Lin, Bartolomé, \& Wood, 2016). Remaja memiliki kecenderungan tinggi melakukan tindakan berisiko seiring dengan peningkatan kematangan fisik dan dorongan seksual (terutama maturasi dini; de Azevedo dkk., 2017), serta tingginya keinginan untuk mendapatkan reward dan lemahnya regulasi diri (Steinberg, 2010). Namun, remaja laki-laki cenderung menganggap perilaku yang dilakukan "tidak/kurang berisiko" dan berani mengambil lebih banyak risiko dibandingkan perempuan. Selain itu, remaja laki-laki juga tidak terlalu memikirkan dengan situasi sosial yang mereka hadapi. Hal ini berbeda dengan perempuan yang cenderung memiliki kecemasan sosial yang lebih tinggi (Reniers, dkk., 2016).

Perilaku berisiko pada remaja laki-laki dan perempuan semakin meningkat intensitasnya jika mereka terlibat dalam geng. Salah satu hal yang perlu diwaspadai dari adanya geng adalah munculnya kekerasan, agresivitas, dan kriminalitas. Cukup banyak penelitian yang telah dilakukan, terutama di Amerika dan Eropa, tentang keterlibatan remaja dalam geng. Beberapa penelitian menemukan bahwa faktor risiko keterlibatan remaja dalam geng antara lain teman sebaya yang melakukan tindakan berisiko, pengasuhan yang buruk, kemiskinan, dan lingkungan tempat tinggal yang buruk (Auyong, Smith, \& Ferguson, 2018; Hautala, Sittner, \& Whitbeck, 2016). Namun, dalam penelitian tersebut, geng yang dimaksud adalah geng jalanan (street gang), bukan geng sekolah.

Penelitian juga menunjukkan bahwa keterlibatan remaja atau dewasa dalam

perilaku berisiko, baik sendiri maupun kelompok, dapat dideteksi mulai dari masa anak. Beberapa hasil penelitian telah menggambarkan bagaimana developmental pathway pada remaja yang melakukan perilaku berisiko, misalnya pada remaja laki-laki yang melakukan seks bebas (Sitnick, Brennan, Forbes, \& Shaw, 2014), remaja dengan externalizing behavior (Reef, Diamantopoulou, Van Meurs, Verhulst, \& Van Der Ende, 2011), dan remaja pecandu alkohol (Englund, Egeland, Oliva, \& Collins, 2008). Dengan melihat developmental pathway, peneliti dapat melihat faktor apa saja yang berperan 
dalam terbentuknya penyimpangan perilaku. Kerig, Ludlow, dan Wenar (2012) mengungkapkan bahwa psikopatologi berkembang karena adanya multifaktor, bukan hanya karena faktor tunggal.

Salah satu contoh model integratif developmental pathaway diberikan oleh Petterson, dkk. (dalam Kerig dkk., 2012). Para peneliti tersebut memberikan contoh tentang developmental pathway dari conduct disorder berdasarkan beberapa hasil penelitian, observasi, dan pengalaman mereka. Pada model tersebut, peneliti menunjukkan bahwa gangguan perilaku terjadi dalam rangkaian yang bertahap yang saling berkaitan satu sama lain. Tahap pertama terjadi pada masa kanak-kanak awal karena orangtua memiliki strategi pengasuhan yang buruk yang membuat anak menjadi antisosial dan memiliki harga diri yang rendah. Tahap kedua terjadi pada saat anak mulai masuk sekolah (masa kanak-kanak tengah) di mana perilaku anti sosial menyebabkan anak ditolak oleh teman sebaya dan memiliki performansi akademik yang buruk. Selanjutnya, hal ini akan membuat anak memiliki sikap negatif terhadap sekolah dan otoritas, dan mengakibatkan mereka terlibat tindak kenakalan/kekerasan pada saat masuk masa remaja (tahap ketiga). Terakhir, remaja dengan perilaku antisosial (termasuk tindak kekerasan) cenderung menghadapi masalah saat dewasa, seperti karir yang tidak jelas, pernikahan yang gagal, dan terlibat dalam tindak kriminal. Siklus ini terjadi secara bertahap dan akan menjadi siklus intergenerational saat mereka sudah dewasa dan memiliki anak-anak.

Maraknya fenomena klithih telah membuat berbagai pihak turun tangan menganalisis faktor penyebab sekaligus upaya mengatasinya. Klithih menjadi fenomena yang cukup unik karena pelaku terlibat dalam geng sekolah, bukan geng umum atau jalanan yang selama ini banyak diteliti di negara lain. Pelaku klithih merupakan individu yang sedang mengenyam pendidikan dan tidak berasal dari lingkungan yang sangat buruk. Di Indonesia, penelitian tentang dinamika geng dan perilaku berisiko sendiri juga belum banyak. Peneliti baru menemukan beberapa artikel yaitu tentang tentang perilaku berisiko komunitas geng motor di Makasar (Saudi, Hartini, \& Bahar, 2018), pengaruh faktor keluarga pada komunitas geng motor di Bandung (Raharjo, Humaedi, \& Taftazani, 2012), dan perilaku agresif pada komunitas geng motor di Medan (Hasmayni, 2016). Oleh karena itu, penelitian tentang klithih ini diharapkan dapat menambah pemahaman tentang keterlibatan remaja dalam geng di sekolah.

Sejauh ini juga belum banyak diungkap, utamanya dari sisi psikologi perkembangan, tentang apa penyebab remaja melakukan klithih dan bagaimana developmental pathway perilaku klithih. Jika faktor penyebab dan developmental pathway para pelaku klithih dapat diketahui, kita akan memiliki gambaran bagaimana perilaku klithih ini berkembang. Apakah indikasi perilaku ini sudah dapat diamati sejak kecil atau muncul mulai saat remaja? Faktor apakah (keluarga, sekolah, masyarakat, atau lainnya) yang berperan penting dalam terbentuknya perilaku klithih ini? Jawaban tentang hal ini juga akan bermanfaat sebagai dasar prevensi klithih di Yogyakarta, yang mungkin bisa dibuat tidak hanya dalam konteks individual tetapi juga dalam konteks yang lebih luas (keluarga, sekolah, masyarakat, ataupun pemerintah).

\section{Metode Penelitian}

Penelitian ini merupakan sebuah penelitian kualitatif yang bertujuan untuk memahami fenomena yang terjadi pada responden yang dijelaskan secara menyeluruh 
dengan cara digambarkan dalam bentuk kata-kata dan bahasa pada suatu konteks alamiah (Moleong, 2002). Data-data yang diperoleh dalam penelitian kualitatif dikumpulkan terutama dalam bentuk bahasa lisan maupun tertulis (Polkinghorne, 2005). Penelitian ini dilakukan dengan bekerjasama dengan pihak Kemenkumham DIY, terutama LPKA Wonosari Lapas IIB Gunung Kidul, Yogyakarta.

Responden

Responden dalam penelitian ini adalah anak didik di LPKA Wonosari yang terlibat kasus klithih di Bantul pada Desember 2016. Responden terdiri dari 10 orang remaja siswa SMA berusia 15-17 tahun (saat ditangkap) yang harus menjalani masa tahanan mulai dari 3 hingga 5 tahun akibat perbuatan klithih yang mengakibatkan jatuhnya korban jiwa. Perbedaan masa tahanan yang harus dijalani berdasarkan tingkat keterlibatan mereka dalam kasus klithih. Detil profil responden penelitian dapat dilihat pada Tabel 1.

Metode pengumpulan data

Metode utama pengumpulan data dalam penelitian ini adalah wawancara, studi dokumen. Wawancara dilakukan secara mendalam terhadap responden yaitu 10 anak didik lapas (andikpas) LPKA Wonosari. Studi dokumen dilakukan dengan mempelajari dokumen terkait data diri dan riwayat responden maupun keluarga dengan seizin pihak LPKA. Selain kedua metode tersebut, peneliti juga menggunakan tes inteligensi untuk mendapatkan data tambahan. Pengumpulan data dilakukan dalam beberapa kali kunjungan di LPKA Wonosari.

Tabel 1

Profil responden penelitian

\begin{tabular}{lcccc}
\hline No. & Inisial & Usia saat awal ditahan & Kelas & Vonis \\
\hline 1. & A & 17 th $8 \mathrm{bl}$ & 11 & 3 th \\
2. & B & 16 th $2 \mathrm{bl}$ & 10 & 3 th \\
3. & C & 17 th $4 \mathrm{bl}$ & 11 & 5 th \\
4. & D & 16 th $2 \mathrm{bl}$ & 11 & 5 th \\
5. & E & 16 th $5 \mathrm{bl}$ & 11 & 3 th \\
6. & F & 17 th $9 \mathrm{bl}$ & 11 & 3 th \\
7. & G & 16 th $9 \mathrm{bl}$ & 11 & 3 th \\
8. & H & 16 th $7 \mathrm{bl}$ & 11 & 3 th \\
9. & I & 16 th $8 \mathrm{bl}$ & 10 & 4 th \\
10. & J & 15 th $3 \mathrm{bl}$ & 10 & \\
\hline
\end{tabular}

\section{Hasil dan Pembahasan}

Berdasarkan analisis data, ada tiga faktor risiko yang diperoleh, yaitu: 1) Relasi buruk dengan orangtua; 2) Komitmen dengan kelompok teman sebaya yang berperilaku menyimpang; dan 3) Rendahnya motivasi akademik. Selain itu, ditemukan juga adanya riwayat perilaku kekerasan sejak kecil (lihat Tabel 2). 
Tabel 2.

Tema dan kategori

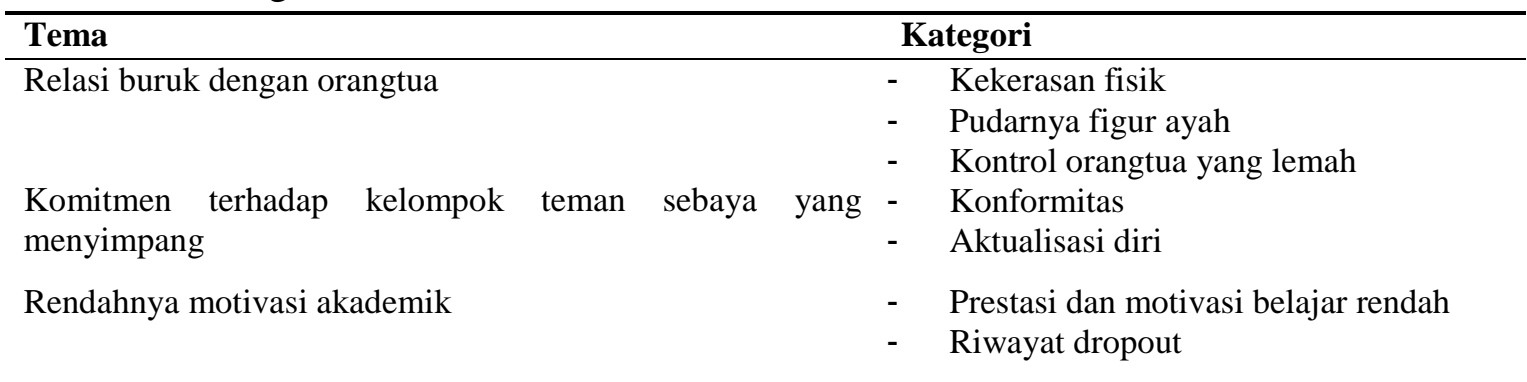

\section{Tema 1: Relasi Buruk dengan Orangtua}

\section{Kekerasan Fisik}

Sejumlah lima dari sepuluh partisipan menyatakan mengalami kekerasan fisik, seperti dipukul atau ditendang oleh orangtua. Kekerasan seringkali dilakukan oleh orangtua dan perilaku ini tidak hanya dilakukan di rumah tetapi juga di muka umum. Apa yang dilakukan oleh orangtua ini sangat membekas dan sulit dilupakan oleh partisipan.

"Aku sering dipukul dari kecil... pernah dipukul di tempat umum, waktu itu lagi main. Bapak datang langsung marah dan memukul, aku ditendang dan dipukul pake sabuk." (D)

"Saya pernah dikurung di kamar mandi waktu kecil, dan tidak dikasih tahu alasannya apa." (F)

\section{Pudarnya figur ayah}

Mayoritas partisipan merasa tidak diperdulikan dan merasa diabaikan oleh ayah. Hal ini ditunjukkan dengan sikap ayah yang cenderung cuek, dingin, dan kurang perhatian dibandingkan sikap ibu. Selain itu, ada juga yang merasa ayah lebih menyayangi saudara yang lain. G, misalnya, merasa kecewa karena ayahnya menunjukkan sikap perhatian terhadap kakaknya, namun tidak terhadap dirinya.

"Ayah lebih perhatian sama kakak dibanding saya.... ditanya, dikasih, dijak ngomong. Jengkel saya mbak.. seperti tidak punya bapak."

Dua orang partisipan bahkan tidak mengenal ayahnya sejak kecil dan sangat merindukan sosok ayah. Ketiadaan ayah menjadi kekosongan tersendiri di hati partisipan.

"Saya kecewa, kesal, tapi tuh pengen banget ngerasain kayak mana rasanya dimarahi ayah. Meskipun belum pernah ketemu tuh saya membayangkan seandainya saya punya ayah. Selama ini saya hanya dengar dari cerita orangorang." (B)

\section{Kontrol orangtua yang lemah}

Mayoritas partisipan mengatakan bahwa orangtua cenderung membebaskan partisipan dalam beraktivitas dan dalam memilih teman. Jikapun ada kontrol, hal itu 
dirasa tidak begitu kuat. Orangtua cenderung membebaskan apa yang dilakukan anak asalkan anak bertanggung jawab. Namun, tanggung jawab yang dipercayakan oleh orangtua ini justru dianggap sebagai celah oleh partisipan untuk bisa berbohong, membolos, atau pulang larut malam.

"Nggak ada Mba, Ibu ngatur atau melarang, yang penting saya tanggung jawab. Saya pulang pagi pernah jam 4 atau 5. Pulang malam sering jam 9 atau 10, udah di rumah. Jam 2 juga, tapi saya bawa buku, kan ibu ngga marah. ” (H)

Kontrol yang lemah juga terlihat pada pengaturan uang yang diterapkan dalam keluarga. Sebagian partisipan mengatur pengeluarannya sendiri dengan tidak ada kontrol terhadap penambahan uang yang diminta oleh partisipan. Hal ini dikarenakan partisipan selalu dapat memberi alasan yang meyakinkan supaya uang jajan mereka ditambah, seperti contoh meminta tambahan uang jajan untuk tambahan biaya les padahal sebenarnya untuk digunakan untuk membeli uang rokok dan minum-minuman keras.

\section{Tema 2: Komitmen terhadap kelompok teman sebaya yang menyimpang Konformitas}

Semua partisipan mengungkapkan bahwa mereka berusaha menyesuaikan diri dengan kelompok karena merasa nyaman ketika bersama dengan teman-teman gengnya dibanding ketika bersama dengan keluarga. Beberapa partisipan juga khawatir jika tidak mengikuti kegiatan geng/kelompok, mereka akan dianggap tidak setia kawan. Pengakuan dan penerimaan dari teman menjadi sesuatu yang penting bagi mereka.

"Nanti gimana kalau ga ikutan (membolos), nanti dikira ga solider." (A)

"Ga enak kalau ga ikut tawuran, saya pernah disindir teman-teman (karena ga ikut)" (F)

Kelompok juga menjadi sumber dukungan dan kehangatan bagi partisipan. Hal yang tidak mereka peroleh dalam keluarga dapat mereka peroleh di dalam kelompok. Selain itu, partisipan merasa bahwa teman-temannya dapat diajak berbagi saat senang maupun susah, lebih pengertian, peduli, nyaman untuk berbagi cerita, dan saling melindungi. Berkumpul bersama teman juga membuat mereka merasa bebas dan bisa menjadi diri sendiri.

"Lebih nyaman kalo bersama dengan teman, kalo sama orangtua takut salah ngomong." (A)

"Rasanya tuh asyik, sama keluarga ga asyik dan ga bebas." (C)

Beberapa partisipan juga merasa senasib dengan anggota gengnya karena kesamaan pernah tertolak di sekolah sebelumnya sehingga drop out dan berpindah ke sekolah yang baru. Beberapa hal lain yang membuat partisipan merasa mempunyai hubungan kuat antara anggota geng adalah karena tidak ada teman lain yang mampu memahaminya. Partisipan merasa tertolak ketika harus bergabung dengan teman-teman 
lain, terlebih dengan status partisipan yang sudah mempunyai riwayat tinggal kelas, drop out, dan dilabel sebagai anak nakal.

\section{Aktualisasi diri}

Keterlibatan dalam kelompok juga dianggap sebagai wujud aktualisasi diri. Hal ini sulit partisipan lakukan ketika berada di lingkungan rumah, sekolah, atau kelompok teman yang lain. Namun, aktualiasasi diri yang mereka lakukan sayangnya bukan sesuatu yang positif, misalnya dalam bidang akademis atau olahraga. Wujud aktualisasi diri yang dilakukan justru hal yang negatif seperti membuat pesta minuman keras dan tawuran. Bagi mereka, aktualisasi diri ini bisa memunculkan perasaan bangga dan kepuasan.

"Terlihat keren dan bangga seperti Jend. Soedirman. Sebenernya saya ikut tawuran karena salah pikiran. Saya ngefans sama Jendral Soedirman. Keren, berperang sambil ditandu-tandu Mbak, jadi panutan saya. Nah, Mbak, X (sekolah) itu kan di jalan S. Jadi ada rasa gimana gitu, keren aja setelah tawuran." (H)

Selain itu, perasaan bangga ditunjukkan dengan sikap arogan dan show off. Salah satu partsipan (D) menyatakan bahwa dia melakukan klithih untuk menunjukkan bahwa dirinya benar-benar seperti apa yang dilabel padanya (negatif). Ia merasa lingkungan sudah terlampau melabel dirinya negatif dan ia merasa tidak memiliki label positif lagi dalam dirinya. Partisipan lain (B) menambahkan bahwa kebanggaan muncul karena ia merasa memiliki peran ketika berada di dalam anggota kelompok gengnya. Partisipan ini berperan sebagai pencari dana dan pengumpul massa sehingga ia merasa diberikan kepercayaan dan merasa berdaya ketika berada dalam kelompoknya.

\section{Tema 3: Rendahnya motivasi akademik Prestasi dan motivasi belajar rendah}

Berdasarkan data hasil tes inteligensi, skor inteligensi partisipan beragam. Empat partisipan menunjukkan skor inteligensi kurang, sedangkan lainnya dengan skor rata-rata dan rata-rata atas. Hal ini menunjukkan bahwa buruknya prestasi mereka di sekolah bukan karena disebabkan kapasitas inteligensi, melainkan ada faktor-faktor lain yang berkontribusi terhadap nilai akademik mereka. Salah satu partisipan menyebutkan bahwa ia malas mengikuti pelajaran di kelas karena alasan membosankan dan mengantuk. Partisipan lain juga mengatakan bahwa ia lebih baik membolos dibanding mengikuti pelajaran di kelas yang membosankan. Dari hal ini dapat disimpulkan bahwa partisipan tidak memiliki motivasi untuk belajar dan berprestasi.

\section{Riwayat drop out}

Enam orang partisipan mempunyai pengalaman dikeluarkan dari sekolah. Dua alasan utama mereka dikeluarkan dari sekolah adalah karena (1) buruknya nilai akademik mereka diakibatkan seringnya membolos dan (2) buruknya perilaku mereka dengan sering melakukan tawuran atau melanggar aturan-aturan lain di sekolah. Namun, meski partisipan sudah dikeluarkan dari sekolah, mereka tetap bisa berkumpul kembali dengan anggota geng sekolah sebelumnya karena mempunyai akses media sosial yang memudahkan mereka untuk membuat janji bertemu. 


\section{Riwayat perkembangan (developmental pathway) perilaku kekerasan}

Semua partisipan menceritakan bahwa sedari kecil mereka sudah sering melakukan kenakalan. Sembilan partisipan sudah merokok bersama kelompok teman sebaya sejak duduk di bangku Sekolah Menengah Pertama (SMP), sedangkan satu partisipan melaporkan bahwa ia mulai merokok sejak duduk di bangku Sekolah Dasar (SD). Mayoritas partisipan juga mencoba minuman beralkohol sejak duduk di bangku SMP, bahkan ada beberapa partisipan yang sudah mencoba narkotika berupa ganja sejak SMP.

Selain merokok, mengonsumsi minuman keras, dan mengosumsi ganja, semua partisipan juga sudah terlibat tindak kekerasan sejak masa kanak-kanak. Delapan partisipan mengaku sering berkelahi sejak mereka duduk di bangku Sekolah Dasar. Penyebab mereka berkelahi kadang bahkan hal-hal yang sangat sepele. Selain itu, salah satu partisipan mengaku bahwa sudah mengenal tawuran sejak duduk di bangku SMP. Kemudian mulai duduk di bangku SMA semua partisipan masuk dalam geng klithih. Keterlibatan mereka dalam tindak kekerasan dan geng klithih diawali dari nongkrong atau berkumpul bersama teman-teman. Hasil ini menunjukkan bahwa onset awal masalah perilaku pada masa kanak-kanak, terutama agresivitas dan perilaku merusak/disruptif, merupakan faktor risiko yang sangat signifikan untuk perilaku sosial dalam masa selanjutnya (Adams \& Berzonsky, 2008). Anak yang melakukan tindak kriminalitas umumnya akan menjadi pelaku kriminal kronik pada masa remaja atau dewasa, dengan indikasi perilaku agresif dan anti sosial yang kontinyu.

Para pelaku kekerasan ini juga memiliki kemiripan riwayat perkembangan (developmental pathway). Ada latar belakang buruknya relasi dengan orang tua yang menjadi faktor risiko berkembangnya perilaku kekerasan. Relasi yang buruk antara remaja dan orang tua ini bukan relasi yang dibangun tiba-tiba, tetapi merupakan kelanjutan dan hasil dari relasi sejak masa kanak-kanak. Terdapat kekerasan fisik yang dialami oleh anak yang akhirnya berdampak juga secara psikologis. Bagaikan dua sisi mata uang, anak mengalami kekecewaan sekaligus kerinduan terhadap orangtua. Beberapa penelitian lain menunjukkan pula bahwa praktik pengasuhan yang negatif, dengan adanya kekerasan fisik, menjadi prediktor tingginya masalah perilaku anak (Alampay et al., 2017; Braga, Gonçalves, Basto-Pereira, \& Maia, 2017; Gershoff \& Grogan-Kaylor, 2016). Anak yang mendapat kekerasan fisik bahkan cenderung meniru tindak kekerasan yang dilakukan orangtua dan kemudian makin mengembangkan perilaku ini ketika mereka remaja.

Buruknya relasi dan kontrol dengan orangtua membuat anak mudah melakukan kenakalan, yang awalnya diawali dari hal 'sederhana' seperti berbohong terus menerus. Padahal kontrol dan kedisiplinan yang konsisten seharusnya menjadi kunci dalam pengasuhan. Relasi dan kontrol dari orang tua akan memfasilitasi anak agar bisa memiliki kematangan emosi yang lebih baik (Longmore, Manning, \& Giordano, 2012). Pada saat anak memasuki masa remaja, tidak berarti orangtua menjadi lebih keras atau lebih longgar dalam mengawasi dan mendidik anak. Namun, hubungan orangtua dan remaja berubah menjadi hubungan yang lebih setara, interdependen, dan resiprokal. Konflik antara orang-tua remaja memang cenderung lebih intens, tetapi hal ini justru seharusnya menjadi wadah untuk mengasah negosiasi konflik dan perubahan relasi (Branje, 2018). Anak akan belajar untuk menyesuaikan antara harapannya dengan harapan orangtua, terutama dalam melihat masa depan.

Hasil penelitian ini juga menunjukkan besarnya peran ayah bagi anak. Hal ini konsisten dengan hasil penelitian Petterson (dalam Kerig et al., 2012) bahwa strategi 
pengasuhan yang buruk dari orangtua (misalnya, dispilin yang tidak konsisten, kurangnya keterlibatan orang tua, kurangnya penguatan positif untuk anak) akan mendorong anak memiliki masalah perilaku. Kehilangan dan kerinduan adanya figur orangtua, terutama ayah, menimbulkan luka tersendiri bagi anak. Banyak penelitian menunjukkan bahwa ayah berperan besar dalam pengasuhan dengan menjadi role model, mendisiplinkan, meningkatkan keterampilan sosial, mendukung performansi akademis, dan menjamin kesejahteraan finansial dan psikologis (East, Jackson, \& O’Brien, 2006; Gordon, 2017; Su, Kubricht, \& Miller, 2017). Kurangnya keterlibatan atau kurang hangatnya hubungan ayah dengan anak dapat menjadi faktor risiko munculnya masalah perilaku anak. Penelitian yang dilakukan di Italia menemukan bahwa para pelaku kriminal mengalami penolakan oleh ayah dan mengalami kekerasan di keluarga sejak mereka kecil (Grattagliano dkk., 2015). Penelitian lain juga menemukan bahwa perilaku negatif dari ayah secara intens seperti memberikan hukuman fisik, marah, dan bersikap keras terhadap anak mengganggu proses kelekatan anak dengan ayah dan meningkatkan berkembangnya perilaku menyimpang (Lee, Pace, Lee, \& Knauer, 2018; Su dkk., 2017).

Disfungsi keluarga ini membuat anak kurang memiliki motivasi belajar dan berprestasi rendah. Penelitian sebelumnya tentang prestasi belajar dan perilaku kekerasan remaja menunjukkan bahwa rendahnya kecerdasan (IQ) menjadi faktor risiko perilaku antisosial dan tindak kekerasan (Murray \& Farrington, 2010). Namun, pada penelitian ini, sebagian besar partisipan memiliki kecerdasan rata-rata dan di atas rata-rata sehingga kecerdasan mungkin bukan faktor penyebab prestasi rendah dan berkembangnya perilaku kekerasan. Buruknya pengasuhan, yang tercermin dari kurangnya pengawasan dan perhatian dari orangtua tentang perkembangan pendidikan anak-anaknya diduga yang menjadi pemicunya. Padahal pengasuhan orangtua, terutama dengan tipe authoritative, sangat berperan dalam pencapaian akademis anak (Masud, Thurasamy, \& Ahmad, 2015). Beberapa partisipan juga menyatakan bahwa orangtua jarang menanyakan tentang aktivitas mereka di sekolah dan tidak ada tindakan yang tegas dari orangtua ketika mereka melakukan pelanggaran di sekolah. Tinggal kelas dan pindah sekolah sekolah juga menjadi hal yang biasa bagi mereka.

Performansi akademik yang buruk tersebut dikarenakan motivasi belajar yang rendah yang ditunjukkan antara lain dengan seringnya membolos sekolah. Underachievement dari segi akademik memang lebih sering dilaporkan pada anak dengan gangguan perilaku (Akpan, Ojinnaka, \& Ekanem, 2010). Henricsson dan Rydell (2004) menyebutkan bahwa anak dengan perilaku antisosial cenderung memiliki konflik terhadap guru, menunjukkan lebih banyak perilaku negatif kepada guru, serta memiliki persepsi diri yang kurang positif dibanding anak yang tidak memiliki gangguan perilaku. Hal ini kemungkinan membuat guru lebih memilih untuk berhubungan dengan anak yang lebih sedikit mempunyai perilaku negatif dibanding dengan anak yang memiliki gangguan perilaku antisosial, sehingga akan mempengaruhi pencapaian akademik dari siswa yang mempunyai perilaku antisosial.

Rendahnya prestasi akademik dan tindak kekerasan yang biasa partisipan lakukan semenjak kecil membuat mereka mendapat label negatif, baik dari orangtua, teman sebaya yang lain, atau sekolah. Label negatif yang mereka peroleh ini malah membuat mereka semakin berkonflik dan berani melawan otoritas yang lebih kuat (orangtua dan guru). Selain itu, mereka cenderung kesulitan menjalin pertemanan karena merasa ditolak dan tidak nyaman. Perasaan ditolak oleh teman sebaya juga mempengaruhi kemampuan remaja dalam mengelola emosi. Pada penelitian ini, ketika partisipan merasa tidak memiliki label positif dalam dirinya, mereka justru memilih aksi kekerasan sebagai 
bentuk ajang untuk menunjukkan bahwa dirinya benar-benar seperti apa yang dilabel padanya. Hal ini juga bisa dilihat sebagai bentuk defense mechanism berupa reaksi formasi, yang berkorelasi dengan perasaan kecemasan (Cramer, 2006). Beeri dan LevWiesel (2012) mengungkapkan bahwa penolakan dari teman dapat mempengaruhi nilainilai personal dimana akan membuat remaja memiliki penyesuaian emosional yang kurang baik. Studi sebelumnya juga menemukan bahwa penolakan dan kurangnya dukungan keluarga pada masa kanak-kanak individu dapat menyebabkan sulitnya perkembangan keterampilan kompetensi individu, dan memudahkan individu untuk melakukan perilaku menyimpang (Dumas, Prinz, Smith, \& Laughlin, 1999).

Penolakan dari teman sebaya dan konflik dengan orangtua inilah yang kemudian mendorong mereka untuk mencari figur lain, yaitu kelompok atau teman yang juga memiliki perilaku antisosial. Hal ini juga sesuai dengan penelitian tentang pembentukan geng yang menunjukkan bahwa geng terbentuk karena adanya penolakan dari teman sebaya dan afiliasi dengan teman yang perilakunya menyimpang (Chen, Drabick, \& Burgers, 2015). Pada fenomena klithih, kelompok menyimpang yang terbentuk adalah kelompok di sekolah. Kesamaan pengalaman yaitu berperilaku antisosial, buruknya prestasi, adanya label negatif, penolakan dari teman sebaya, dan pengasuhan yang buruk membuat mereka bergabung dalam satu kelompok yang sama. Dalam kelompok ini, mereka merasa mendapat penerimaan, pengakuan, dan dukungan. Konformitas pada kelompok cukup tinggi yang dibuktikan dengan kesediaan untuk ikut tawuran dan menyerang. Muncul perasaan tidak nyaman dan takut dikucilkan jika mereka tidak ikut bergabung dalam kegiatan kelompok, meskipun mereka tahu kegiatan tersebut berisiko dan membahayakan diri sendiri maupun orang lain. Mayoritas partisipan menunjukkan komitmen yang tinggi dengan kelompok teman sebayanya dan menganggap kelompoknya sebagai ajang aktualisasi diri. Selain itu, mereka juga merasa bangga dan mendapat pengakuan di dalam kelompok. Kelompok juga dianggap sebagai sumber dukungan sosial yang penting, bahkan dianggap lebih penting dari keluarga. Perasaan bangga, diterima, dan didukung ini tidak mereka dapatkan ketika berada di luar kelompoknya. Status para partisipan sebagai siswa dropout dan bermasalah justru membuat mereka makin solid satu sama lain. Hal ini sesuai dengan konsep bahwa hubungan pertemanan terbentuk utamanya karena ada kesamaan aktivitas, minat, atau latar belakang sehingga muncul rasa nyaman dan kecocokan (Santrock, 2014). Pada masa remaja, aspek seperti keintiman, komitmen, dan keterbukaan memang lebih menonjol dibandingkan pada masa anak-anak (Pnevmatikos \& Bardos, 2014).

Sebagaimana telah diuraikan di atas, hasil penelitian ini menunjukkan adanya relasi yang buruk antara partisipan dengan orangtua mereka. Namun, peneliti tidak menggali data dari orangtua untuk mendapatkan gambaran yang lebih utuh mengenai relasi mereka dengan anak-anak. Oleh karena itu, bagi penelitian selanjutnya diharapkan dapat menambah data dari orangtua sebagai significant others dalam perkembangan anak.

\section{Simpulan}

Berdasarkan hasil penelitian dapat diambil kesimpulan bahwa faktor risiko perilaku kekerasan yang dilakukan oleh anak bukan semata dari anak sendiri, tapi dari lingkungan di sekitarnya, baik keluarga maupun teman sebaya. Perilaku kekerasan yang dilakukan juga sudah muncul dari kecil, tidak tiba-tiba muncul saat masuk masa remaja. 
Bahayanya, jika riwayat kekerasan ini tidak diputus, perilaku tersebut dapat terus berlanjut atau terulang ke generasi berikutnya (intergenerational transmission). Dengan memahami siklus dan riwayat perkembangan munculnya perilaku kekerasan, salah satu poin penting yang ditemukan adalah pentingnya relasi antara orangtua dan anak. Kedua orangtua diharapkan konsistensi dalam memberikan aturan di dalam rumah. Penerapan disiplin dilakukan secara adil, beralasan, dan konsisten, tanpa melibatkan kekerasan baik secara fisik maupun emosional. Monitoring menjadi peran penting yang dilakukan orangtua pada saat anak memasuki masa remaja, terutama ketika teman sebaya yang kurang baik menjadi sosok yang memberikan pengaruh utama bagi perilaku mereka.

\section{Daftar Pustaka}

Adams, G. R., \& Berzonsky, M. D. (2008). Blackwell handbook of adolescence. Oxford: Blackwell publishing.

Akpan, M. U., Ojinnaka, N. C., \& Ekanem, E. E. (2010). Academic performance of school children with behavioural disorders in Uyo, Nigeria. African Health Sciences. 10(2), 154-158.

Alampay, L. P., Godwin, J., Lansford, J. E., Bombi, A. S., Bornstein, M. H., Chang, L., .Bacchini, D. (2017). Severity and justness do not moderate the relation between corporal punishment and negative child outcomes: A multicultural and longitudinal study. International Journal of Behavioral Development, 41(4), 491-502. http://doi.org/10.1177/0165025417697852

Ashford, J. B., \& LeCroy, C. W. (2010). Human Behavior in the Social Environment: A Multidimensional Perspective (4th ed.). Belmont, CA: Thomson Brooks/Cole.

Auyong, Z. E. G., Smith, S., \& Ferguson, C. J. (2018). Girls in gangs: Exploring risk in a British youth context. Crime and Delinquency, 55(3), 363-387. http://doi.org/10.1177/0011128718763130

Beeri, A., \& Lev-Wiesel, R. (2012). Social rejection by peers: A risk factor for psychological distress. Child and Adolescent Mental Health, 17(4), 216-221. http://doi.org/10.1111/j.1475-3588.2011.00637.x

Bikin miris, dalam sebulan terjadi 4 klithih di Jogja, mayoritas pelaku masih anak-anak. (2018, Juni). Harian Jogja. Diunduh dari http://jogjapolitan.harianjogja.com/read/2018/06/28/510/924889/bikin-mirisdalam-sebulan-terjadi-4-klithih-di-jogja-mayoritas-pelaku-masih-anak-anak.

Braga, T., Gonçalves, L. C., Basto-Pereira, M., \& Maia, Â. (2017). Unraveling the link between maltreatment and juvenile antisocial behavior: A meta-analysis of prospective longitudinal studies. Aggression and Violent Behavior, 33, 37-50. http://doi.org/10.1016/j.avb.2017.01.006

Branje, S. (2018). Development of parent-adolescent relationships: Conflict interactions as a mechanism of change. Child Development Perspectives, O(0), 1-6. http://doi.org/10.1111/cdep.12278

Chen, D., Drabick, D. A. G., \& Burgers, D. E. (2015). A Developmental perspective on peer rejection, deviant peer affiliation, and conduct problems among youth. Child 
Psychiatry and Human Development, 46(6), 823-838. http://doi.org/10.1007/s10578-014-0522-y

Cramer, P. (2006). Protecting the Self: Defense Mechanism in Action. USA: Guilford Press.

De Azevedo, K. P. M., Santos, I. K. D., Dantas, P. M. S., Knackfuss, M. I., Bento, T., de Leitão, J. C., \& de Medeiros, H. J. (2017). Pubertal maturation and health risk behaviors in adolescents: A systematic review. Epidemiology Biostatistics and Public Health, 14(1), 1-7. http://doi.org/10.2427/12156

Dumas, J. E., Prinz, R. J., Smith, E. P., \& Laughlin, J. (1999). The early alliance prevention trial: An integrated set of interventions to promote competence and reduce risk of conduct disorder, substance abuse, and school failure. Clinical Child Family Psychology, 2, 37-53.

East, L., Jackson, D., \& O'Brien, L. (2006). Father absence and adolescent development: a review of the literature. Journal of Child Health Care, 10(4), 283295. http://doi.org/10.1177/1367493506067869

Englund, M. M., Egeland, B., Oliva, E. M., \& Collins, W. A. (2008). Childhood and adolescent predictors of heavy drinking and alcohol use disorders in early adulthood: A longitudinal developmental analysis. Addiction, 103(suppl 1), 23-25. http://doi.org/10.1111/j.1360-0443.2008.02174.x

Gershoff, E. T., \& Grogan-Kaylor, A. (2016). Spanking and child outcomes: Old controversies and new meta-analyses. Journal of Family Psychology, 30(4), 453469. http://doi.org/10.1037/fam0000191

Gordon, M. S. (2017). Self-perception and relationship quality as mediators of father's school-specific involvement and adolescent's academic achievement. Children and $\begin{array}{llll}\text { Youth } & \text { Services } & \text { Review, } & \text { 94-100. }\end{array}$ http://doi.org/10.1016/j.childyouth.2017.04.001

Grattagliano, I., Cassibba, R., Costantini, A., Laquale, G. M., Latrofa, A., Papagna, S., ... Terlizzi, M. (2015). Attachment models in incarcerated sex offenders: A preliminary italian study using the adult attachment interview. Journal of Forensic Sciences, 60(1), 138-42. http://doi.org/10.1111/1556-4029.12652

Gullone, E., \& Moore, S. (2000). Adolescent risk-taking and the five-factor model of personality. Journal of Adolescence, 23(4), 393-407. http://doi.org/10.1006/jado.2000.0327

Hasmayni, B. (2016). Perilaku agresif pada anggota geng motor ditinjau dari tingkat usia dan suku di kota Medan. Jurnal Pendidikan Ilmu-Ilmu Sosial, 8(2), 165-177.

Hautala, D. S., Sittner, K. J., \& Whitbeck, L. B. (2016). Prospective childhood risk factors for gang involvement among North American Indigenous Adolescents. Youth Violence and Juvenile Justice, 14(4), 390-410. http://doi.org/10.1177/1541204015585173

Henricsson, L., \& Rydell, A.-M. (2004). Elementary school children with behavior problems: Teacher-child relations and self-perception. A Prospective Study. Merrill-Palmer Quarterly, 50(2), 111-138. http://doi.org/10.1353/mpq.2004.0012 
Kapolda DIY: Sepanjang 2016, 43 kasus didominasi pelajar. (2016, December). Detiknews. Diunduh dari https://news.detik.com/berita/d-3382743/kapolda-diysepanjang-2016-43-kasus-kriminal-didominasi-pelajar

Kazdin, A. E. (2003). Adolescent development, mental disorders, and decision making of delinquents youth. In T. Grisso \& R. G. Schwartz. Youth on trial: A developmental perspective of juvenile justice. Chicago: The University of Chicago Press.

Kerig, P., Ludlow, A., \& Wenar, C. (2012). Developmental psychopathology (6th ed.). New York: McGraw-Hill education.

Kipping, R. R., Campbell, R. M., MacArthur, G. J., Gunnell, D. J., \& Hickman, M. (2012). Multiple risk behaviour in adolescence. Journal of Public Health, 34(suppl 1), i1-i2. http://doi.org/10.1093/pubmed/fdr122

Klithih menjadi kasus yang paling diwaspadai Polda DIY. (2016, Desember). Harian Jogja. Diunduh dari http://www.harianjogja.com/baca/2016/12/30/kriminaljogja-klithih-menjadi-kasus-yang-paling-diwaspadai-polda-diy-780636

Lee, S. J., Pace, G. T., Lee, J. Y., \& Knauer, H. (2018). The association of fathers' parental warmth and parenting stress to child behavior problems. Children and Youth Services Review, 91, 1-10. http://doi.org/10.1016/j.childyouth.2018.05.020

Longmore, M. A., Manning, W. D., \& Giordano, P. C. (2012). Parent-child relationships in adolescence. In M. A. Fine \& F. D. Fincham (Eds.), Handbook of family theories: A content based approach (pp. 28-50). London: Routledge.

Mangunsuwito, S. A. (2002). Kamus Bahasa Jawa. Bandung: Yrama Widya.

Masud, H., Thurasamy, R., \& Ahmad, M. S. (2015). Parenting styles and academic achievement of young adolescents: A systematic literature review. Quality and Quantity. http://doi.org/10.1007/s11135-014-0120-x

Moleong, J. L. (2002). Metodologi Penelitian Kualitatif. Bandung: Remaja Karya.

Murray, J., \& Farrington, D. P. (2010). Risk factors for conduct disorder and delinquency: Key findings from Longitudinal Studies. The Canadian Journal of Psychiatry, 55(10), 633-642. http://doi.org/10.1177/070674371005501003

Pawlowski, B., Atwal, R., \& Dunbar, R. I. M. (2008). Sex differences in everyday risktaking behavior in humans. Evolutionary Psychology, 6(1), 29-42. http://doi.org/10.1177/147470490800600104

Peake, S. J., Dishion, T. J., Stormshak, E. A., Moore, W. E., \& Pfeifer, J. H. (2013). Risk-taking and social exclusion in adolescence: Neural mechanisms underlying peer influences on decision-making. NeuroImage, 82, 23-34. http://doi.org/10.1016/j.neuroimage.2013.05.061

Pnevmatikos, D., \& Bardos, A. N. (2014). Greek adolescents' intimate relations before their transition to adulthood. Journal of Adolescence, 37(8), 1475-1488. http://doi.org/10.1016/j.adolescence.2014.07.018 
Polkinghorne, D. E. (2005). Language and meaning: Data collection in qualitative research. Journal of Counseling Psychology, 37(8), 1475-1488. http://doi.org/10.1037/0022-0167.52.2.137

Poulin, F., \& Chan, A. (2010). Friendship stability and change in childhood and adolescence. Developmental Review, 30, 257-272. http://doi.org/10.1016/j.dr.2009.01.001

Raharjo, S. T., Humaedi, S., \& Taftazani, B. M. (2012). Faktor keluarga dalam kenakalan remaja: Studi deskriptif mengenai geng motor di kota Bandung. Sosiohumaniora, 14(3), 212-221.

Reef, J., Diamantopoulou, S., Van Meurs, I., Verhulst, F. C., \& Van Der Ende, J. (2011). Developmental trajectories of child to adolescent externalizing behavior and adult DSM-IV disorder: Results of a 24-year longitudinal study. Social Psychiatry and Psychiatric Epidemiology, 46(12), 1233-1241. http://doi.org/10.1007/s00127-010-0297-9

Reniers, R. L. E. P., Murphy, L., Lin, A., Bartolomé, S. P., \& Wood, S. J. (2016). Risk perception and risk-taking behaviour during adolescence: The influence of personality and gender. PLoS ONE, 11(4). http://doi.org/10.1016/j.bbr.2012. 10.002

Santrock, J. W. (2014). A topical approach to life-span development (7th ed.). New York: McGraw-Hill education.

Sarwono, R. B. (2017). Mengendalikan kegaduhan sosial "klithih" dengan ketahanan keluarga. Proceeding Seminar dan Lokakarya Nasional Revitalisasi Laboratorium dan Jurnal Ilmiah dalam Implementasi Kurikulum Bimbingan dan Konseling Berbasis KKNI, 190-201.

Saudi, A. N. A., Hartini, N., \& Bahar, B. (2018). Teenagers' motorcycle gang community aggression from the Personal Fable and risk-taking behavior perspectivele. Psychology Research and Behavior Management, 11, 305-309.

Sitnick, S. L., Brennan, L. M., Forbes, E., \& Shaw, D. S. (2014). Developmental pathways to sexual risk behavior in high-risk adolescent boys. Pediatrics, 133(6), 1038-45. http://doi.org/10.1542/peds.2013-3976

Steinberg, L. (2010). A dual systems model of adolescent risk-taking. Developmental Psychobiology, 52(3), 216-224. http://doi.org/10.1002/dev.20445

Steinberg, L., \& Monahan, K. C. (2007). Age differences in resistance to peer influence. Developmental Psychology, 43(6), 1531-1543. http://doi.org/10.1037/00121649.43.6.1531

Su, L. P., Kubricht, B., \& Miller, R. (2017). The influence of father involvement in adolescents' overall development in Taiwan. Journal of Adolescence. http://doi.org/10.1016/j.adolescence.2017.05.010 